\title{
敬 \\ The application of process mineralogy on a tailings sample from a beach placer deposit containing rare earth elements
}

\author{
by A. Moila*t, D. Chetty*, and S. Ndlovu ${ }^{\dagger \neq}$
}

\section{Synopsis}

The rare earth elements (REE) are significant in the context of world economic growth and modern technology. This research is aimed at investigating an alternative source of REE by exploring cost-effective ways of processing REE minerals from an existing beach placer deposit operation, currently mined for titanium. In order to recover REE through economically optimum means, upfront mineralogical investigations are a necessity to reduce the ore processing costs. An approach involving mineralogical characterization and hydrometallurgical test work was therefore chosen. The sample for the study - a tailings fraction from a heavy mineral concentration plant in the titanium industry - was screened into four size classes, and each size class was mineralogically characterized. The minerals present in the sample were monazite, zircon, epidote, pyroxene, amphibole, rutile, quartz, leucoxene, titanite, and almandine. The main REE-bearing minerals, monazite and zircon, were preferentially concentrated in the finer $(-150 \mu \mathrm{m})$ fractions, which constituted about 50 mass \% of the sample and which would be amenable to direct leaching without prior upgrading to a concentrate. Leaching test work was carried out on the combined fractions passing $150 \mu \mathrm{m}$. Mineralogical examination of the residues from different leach stages showed that monazite was cracked and the REE released to solution in the final leach stage. Zircon was not as reactive under the conditions used, and REE release was not expected from this mineral. The mineralogical findings were correlated against bulk chemical analyses of the leach products to establish whether a good reconciliation was achieved.

Keywords

rare earth elements, beach placer deposit, process mineralogy, leaching.

\section{Introduction}

The rare earth elements (REE), which constitute the lanthanide group in the Periodic Table, are a major constituent of many advanced materials, especially in the high technology and green energy sectors. This group of elements is very important in the world economy and modern technology. Resources of REE are globally distributed, but production is largely monopolised by China, which controls approximately $95 \%$ of the world's REE Market ( Wübbeke, 2013; Massari and Ruberti, 2013).

Early in 2005, China as the leading REE producer decided to limit its REE exports by establishing quotas and banning the sale of some REE outside the country, so as to meet its own domestic requirements (Morrison and Tang, 2012). This resulted in a high global demand and strained supply (Figure 1). As a result, other countries were faced with the challenge of exploring means of closing the REE demand-and-supply deficit gap created by the change in China's export regulations.

The reduction in supply quotas of REE by China led to a drastic increase in global demand for REE, thus creating an opportunity for other countries to look into alternative sources of REE.

Japan made plans to extend the search for highly concentrated REE in deep-sea mud of the Pacific Ocean (Gordon, 2011), as well as to recycle old batteries and electronic equipment for their REE contents and to secure alternative supplies of REE from Mongolia (Tabuki, 2010).

India planned to resuscitate its REE production from Indian Rare Earths Limited (IREL), which ceased production in 2004. Other plans to enhance the development of REE supply in India and Vietnam were made by Toyota Motor Corporation in 2011 and 2013 (Montgomery, 2011).

This paper outlines the approaches used to investigate an alternative REE resource; a byproduct from an existing titanium recovery operation in South Africa. The process involved the characterization of the REE from the beach placer deposit before processing. The investigation was carried out subsequent to China's decision to implement new export regulations limiting REE exports. Research studies have been conducted globally on REE from carbonatite and placer deposits; in particular in China and the USA, which have the world's largest carbonatite-hosted rare earth reserves. Extensive work has been conducted on the South African carbonatite

\footnotetext{
* Mintek, Randburg, South Africa.

+ School of Chemical and Metallurgical Engineering, University of the Witwatersrand, South Africa.

₹ DST/NRF SARChI, Hydrometallurgy and Sustainable Development, University of the Witwatersrand, South Africa.

(C) The Southern African Institute of Mining and Metallurgy, 2017. ISSN 2225-6253. This paper was first presented at the 3rd Young Professionals Conference, 9-10 March 2017, Innovation Hub, Pretoria, South Africa.
} 


\section{The application of process mineralogy on a tailings sample containing REE}

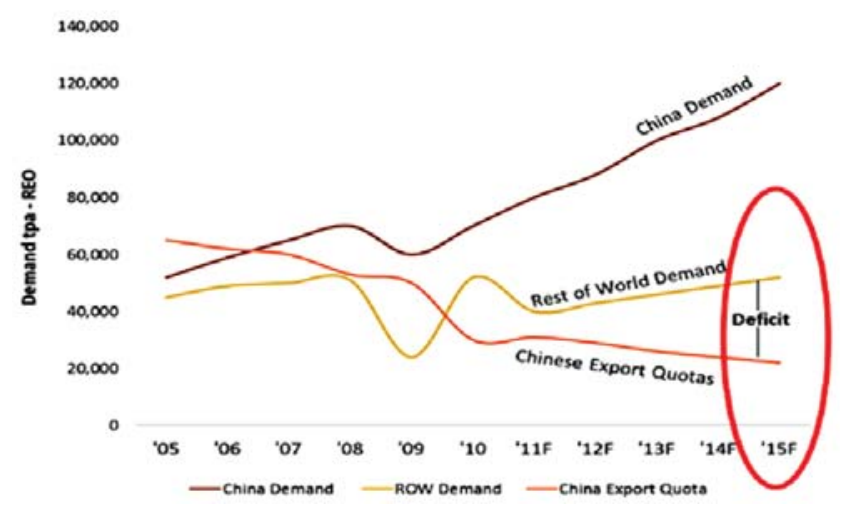

Figure 1-Demand and supply curves, showing an increase in the deficit created by the decline in export of REE from China (Liu, 2011)

deposits, namely, Steenkampskraal and Zandkopsdrift, but very little work has been done on beach placer deposits for REE.

The South African REE deposits are mainly of primary origin, consisting of carbonatite and hydrothermal deposits, accompanied by secondary (beach placer) deposits. The primary carbonatite deposits are associated with igneous and hydrothermal processes, whereas the secondary (placer) deposits are formed by sedimentary processes and weathering (Sappin and Beaudoin, 2015). Beach placer deposits, which constitute the world's second-largest REE reserves (Haxel, Hedrick, and Orris, 2002), occur in Australia, Brazil, China, India, Malaysia, South Africa, Sri Lanka, Thailand, and the USA.

The beach placer deposits in South Africa are mainly mined for titanium and little work has been done on their REE potential, particularly as regards tailings from existing titanium production. Most heavy mineral deposits or beach placer deposits are mined for titanium minerals and zircon, with monazite and leucoxene considered as tailings. The heavy mineral tailings from existing titanium production therefore constitute a potential source of REE as byproducts.

The Eneabba placer deposit in Australia produces titanium as a primary product and monazite as a byproduct. In Australia, monazite is a significant REE resource, with 6.1 Mt processed annually and an estimated 2.1 Mt of rare earth oxides (REO) production reported in 2014 (Roskill, 2015).

Beach placer deposits are naturally deposited sediments along rivers and coastlines, in which common minerals such as monazite, zircon, quartz, ilmenite, garnet, and magnetite are found. Beach placer deposits are mined for titanium hosted in minerals such as ilmenite, rutile, and other titanium and iron alteration products such as leucoxene (Roskill, 2015). Monazite is the chief REE-bearing mineral, although some of the other heavy minerals may contain various REE substitutiing in their crystal structures (Deysel, 2007).

The current study is part of an ongoing research project on the process mineralogy and extraction of REE from beach placers, the ultimate aim being to assess the cost-effective utilization of beach placer tailings from the titanium industry as an additional source of REE. An important aim is to show that mineralogical studies are a vital factor in REE extraction (Pawlik, 2013).
Diverse techniques have been applied by different companies to recover REEs. There are various well-known processes for decomposing the REE-bearing minerals, and in order to select an appropriate beneficiation and leaching method the mineralogy of the ore is an important consideration. In spite of this, very few published flow sheets are accompanied by the process mineralogical aspects, in particular those relating to the products.

Figure 2 shows an idealized flow sheet of REE extraction from primary (bastnaesite) and secondary (monazite) deposits used in the USA and China.

The leaching of REE involves two processing routes, namely the acidic route and the alkaline route, (Figure 2). Leaching is carried out on upgraded material in the form of a concentrate. The concentrates or products are either treated directly by acidic or alkaline reagents, or first undergo thermal treatment prior to leaching (Fatherly et al., 2008). The choice of leaching route is highly dependent on the mineralogy of the ore.

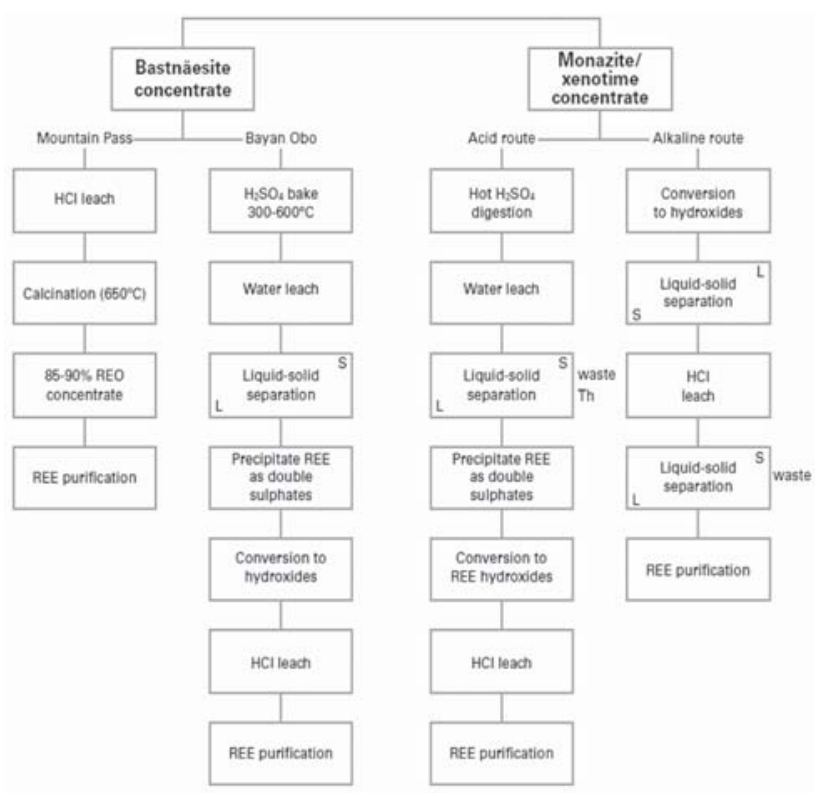

Figure 2-An idealized flow sheet for extracting REE from bastnaesite (carbonatite-hosted REE) and monazite (placer-hosted REE) (Chegwidden and Kingsnorth, 2010) 


\section{The application of process mineralogy on a tailings sample containing REE}

\section{Methods}

\section{Tailings sample characterization}

A tailings sample from a South African beach sand titanium operation was split into four size fractions: $+212 \mu \mathrm{m},-$ $212+150 \mu \mathrm{m},-150+106 \mu \mathrm{m}$, and $-106 \mu \mathrm{m}$.

Each size fraction was weighed and recorded (Table I).

Each fraction was individually characterized using X-ray diffraction (XRD), optical microscopy, scanning electron microscopy (SEM), electron microprobe analysis (EMPA), and automated SEM.

\section{$X$-ray diffraction analysis}

$\mathrm{X}$-ray powder diffraction was used for phase identification of the crystalline minerals, to provide information on the bulk mineralogy of the sample. Pulverized samples were subjected to analysis using a Bruker D8 Advance diffractometer with Co $K \alpha$ radiation, a $2 \theta$ scan range of $5-80^{\circ}$, a step size of $0.02^{\circ}$ $2 \theta$, and a counting time of 3 seconds per step. Note that only crystalline minerals present in mass percentages greater than approximately $3 \%$ are detected by this method.

\section{Optical microscopy/SEM analysis}

Polished sections were prepared for examination using the reflected light microscope and a Zeiss EVO MA1 SEM. The reflected light microscope was used to identify REE-bearing and gangue minerals, as well as to determine their mode of occurrence in each of the size fractions. The Zeiss EVO MA1 SEM, equipped with quantitative energy dispersive spectrometry (EDS), was used to verify the presence of REEbearing minerals and to determine their elemental compositions.

Elemental maps were captured to illustrate and verify the mode of occurrence of REE-bearing minerals and other elements associated with REE minerals. Element mapping is a procedure available on the SEM where specific selected chemical elements can be 'searched' within a microscopic field of view, and the relative concentrations of the element are illustrated with different selected colours. If one particular element is present in a particle, the specific particle is highlighted with the colour for that element.

When particles contain more than one mineral phase, the individual element colour concentration is highlighted according to its occurrence in the minerals. If the element is absent an overall background colour appears.

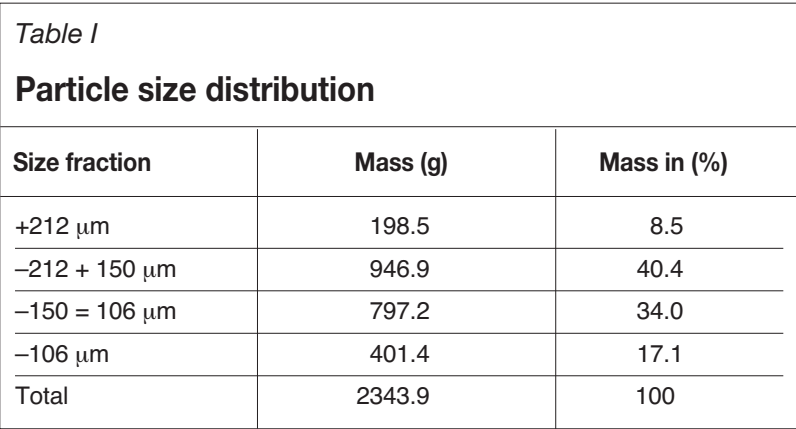

\section{Electron microprobe analysis}

A Cameca SX50 electron microprobe equipped with four wavelength dispersive spectrometers (WDS) was used to determine the mineral chemistry on various grains. A maximum of 365 grains were analysed in all size fractions. REE calibration was performed using the REE orthophosphate reference samples from the Smithsonian Microbeam Standards collection. Other elements analysed were calibrated using appropriate reference standards. The standard excitation conditions used were $20 \mathrm{kV}$ and $30 \mathrm{nA}$, with a spot size of $5 \mu \mathrm{m}$.

\section{AutoSEM analysis}

A Mineral Liberation Analyser (MLA) was used to quantitatively distinguish the mineral abundance in the sample. The measurement mode employed in this study was extended backscattered electron liberation analysis (XBSE). The XBSE mode implements area X-ray analysis to efficiently and effectively analyse ore samples containing phases with sufficient BSE contrast to ensure effective segmentation. The BSE image is then captured and segmented to delineate mineral grain boundaries in each particle. Each mineral grain is then subjected to X-ray analysis (Gu, 2003).

\section{Hydrometallurgical test work and mineralogical evaluation of products}

The detailed mineralogical analysis showed that monazite and zircon were preferentially concentrated in the finer fractions $(-150 \mu \mathrm{m})$, which constituted approximately 50 mass $\%$ of the sample (Figure 4 ). The $+212 \mu \mathrm{m}$ and $-212+150 \mu \mathrm{m}$ fractions contained only trace amounts of monazite and zircon. The $-150+106 \mu \mathrm{m}$ and $-106 \mu \mathrm{m}$ size fractions were composited to form a $-150 \mu \mathrm{m}$ sample (referred to as the composite sample), and a mass of $400 \mathrm{~g}$ was ground using a ball mill to $100 \%$ passing $45 \mu \mathrm{m}$ for subsequent hydrometallurgical test work.

The composite sample was subjected to a series of hydrometallurgical tests that involved caustic cracking, water leaching, and selective leaching (Figure 3). Sub-samples were taken from each leaching stage and washed for mineralogical characterization using the Zeiss EVO MA1 SEM.

Caustic cracking involves the decomposition of monazite using 50\% (m/m) NaOH solution (Gupta and Krishnamurthy, 2005), with the aim being to break down the monazite ((Ce,La,Nd,Th) $\mathrm{PO}_{4}$ ) into trisodium phosphate and REE hydroxides. The caustic cracking was conducted for 4 hours using $50 \%(\mathrm{~m} / \mathrm{m}) \mathrm{NaOH}$ solution at a temperature of $140^{\circ} \mathrm{C}$, in a $5 \mathrm{~L}$ stainless steel reactor.

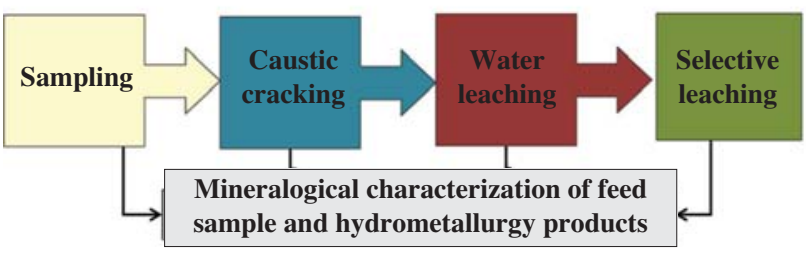

Figure 3-Experimental approach 


\section{The application of process mineralogy on a tailings sample containing REE}

The cracked residue was washed three times using deionized water to remove the majority of the entrained $\mathrm{NaOH}$ (Mokoena, 2016).

The washed residue was leached with water to convert the REE into hydroxides, followed by selective leaching of the REE using $32.0 \% \mathrm{HCl}$ in a $3 \mathrm{~L}$ thermoplastic coated reactor. The lixiviant temperature was ambient, with the recorded redox potential averaged at $441.8 \mathrm{mV}$. After each leaching stage, the residues were washed prior to the next leaching stage. Samples of the residues from each leaching and washing stage were taken for mineralogical characterization.

A total of ten leach and washed residues were prepared and were mounted on a carbon-coated stub for examination by SEM, using a Zeiss EVO MA1 instrument equipped with EDS, in order to identify REE-containing phases and determine their compositions.

\section{Results and discussion}

\section{Mineralogy of the tailings samples}

The mineralogical results derived from the autoSEM analysis showed that the sample consisted of monazite, zircon, amphibole, diopside, augite, epidote, rutile, quartz, leucoxene, titanite, and almandine. Monazite and zircon were the chief REE-containing minerals. The mineralogy of the sample varied per size fraction. The coarser fractions (+212 $\mu \mathrm{m}$ and $-212+150 \mu \mathrm{m})$ were dominated by epidote, followed by minor amounts of diopside, augite, and amphibole. Mineralogical variations were more evident in the two smallest size fractions $(-150+106 \mu \mathrm{m}$ and $-106 \mu \mathrm{m})$, which contained the majority of the zircon, rutile, and monazite and which together constituted approximately 50 mass \% of the tailings sample (Figure 4). Based on these findings, a composite of these size fractions was further subjected to REE extraction test work.

\section{Mineralogy of the hydrometallurgical test products}

Mineralogical characterization of the ten leach and washed residues showed distinctive changes in each

hydrometallurgical stage.

\section{Caustic crack residues}

The $\mathrm{NaOH}$ crack residues were studied and the findings showed that the phosphate ion was successfully cracked from the monazite ((Ce,La,Nd,Th) $\left.\mathrm{PO}_{4}\right)$. However, the zircon grains did not appear to have reacted with the $\mathrm{NaOH}$ (see Figure 5, $\mathrm{NaOH}$ crack sample on grains number 3 and 5).

Subsequent to $\mathrm{NaOH}$ cracking, the residues were washed three times in order to remove the entrained $\mathrm{NaOH}$ solution prior to water leaching and $\mathrm{HCl}$ leaching. The two repulp washing results on the residue showed a general decrease in Na content relative to the unwashed cracked residue (Table II). The zircon grains showed very little reaction with $\mathrm{NaOH}$; this is indicated by high $\mathrm{Zr}$ and Si values, very similar to the original zircon composition (Table II).

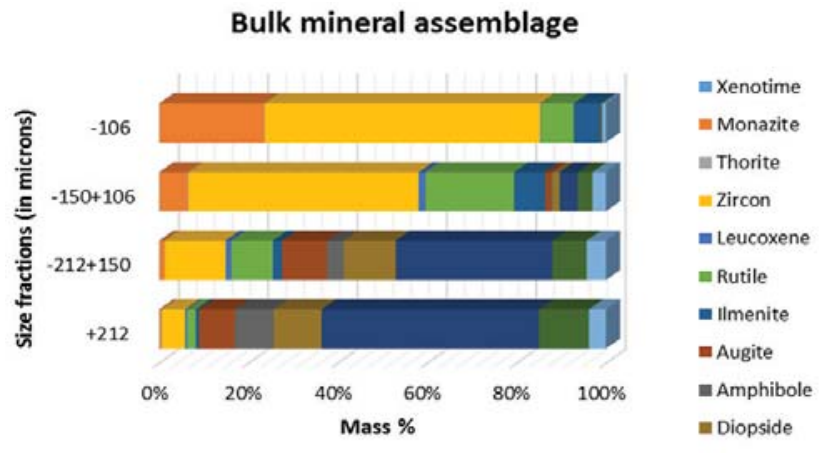

Figure 4-Bulk mineral assemblage of the tailings sample
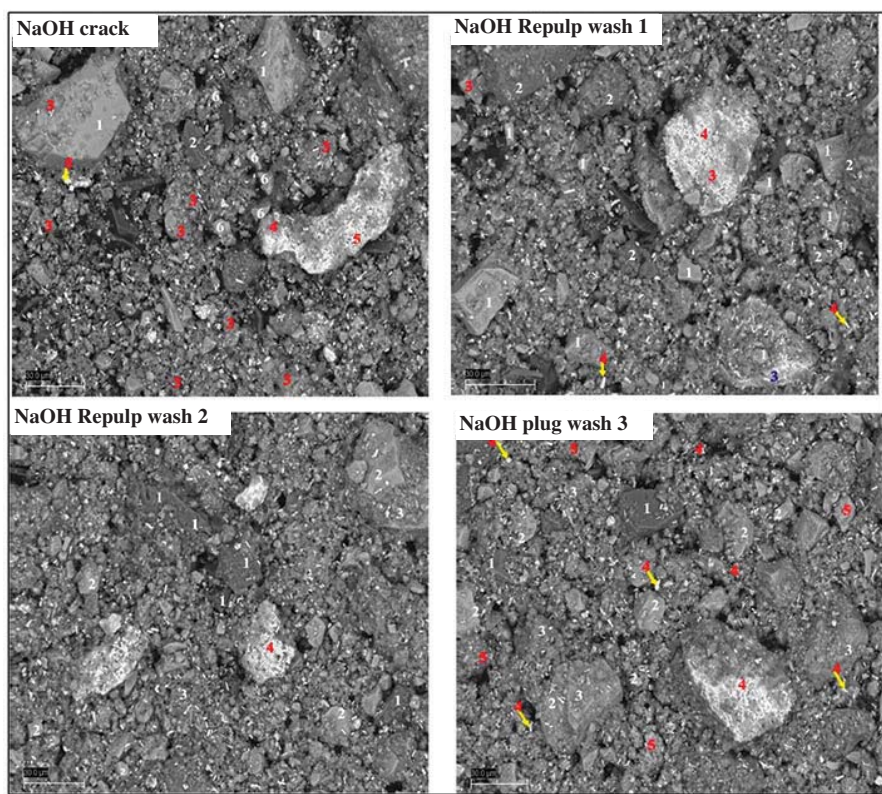

Figure 5-Backscattered electron (BSE) images of residues from caustic cracking and washing tests; analyses of the numbered points are given in Table II. The BSE images also show the cracked monazite grains and unreacted zircon. (Point 2 of $\mathrm{NaOH}$ crack was identified as an oxide phase; points 2 and 3 of $\mathrm{NaOH}$ repulp wash 1 and point 2 of $\mathrm{NaOH}$ repulp wash 2, as well as points 1,3 and 5 of $\mathrm{NaOH}$ plug wash 3 , refer to oxide and silicate phases) 


\section{The application of process mineralogy on a tailings sample containing REE}

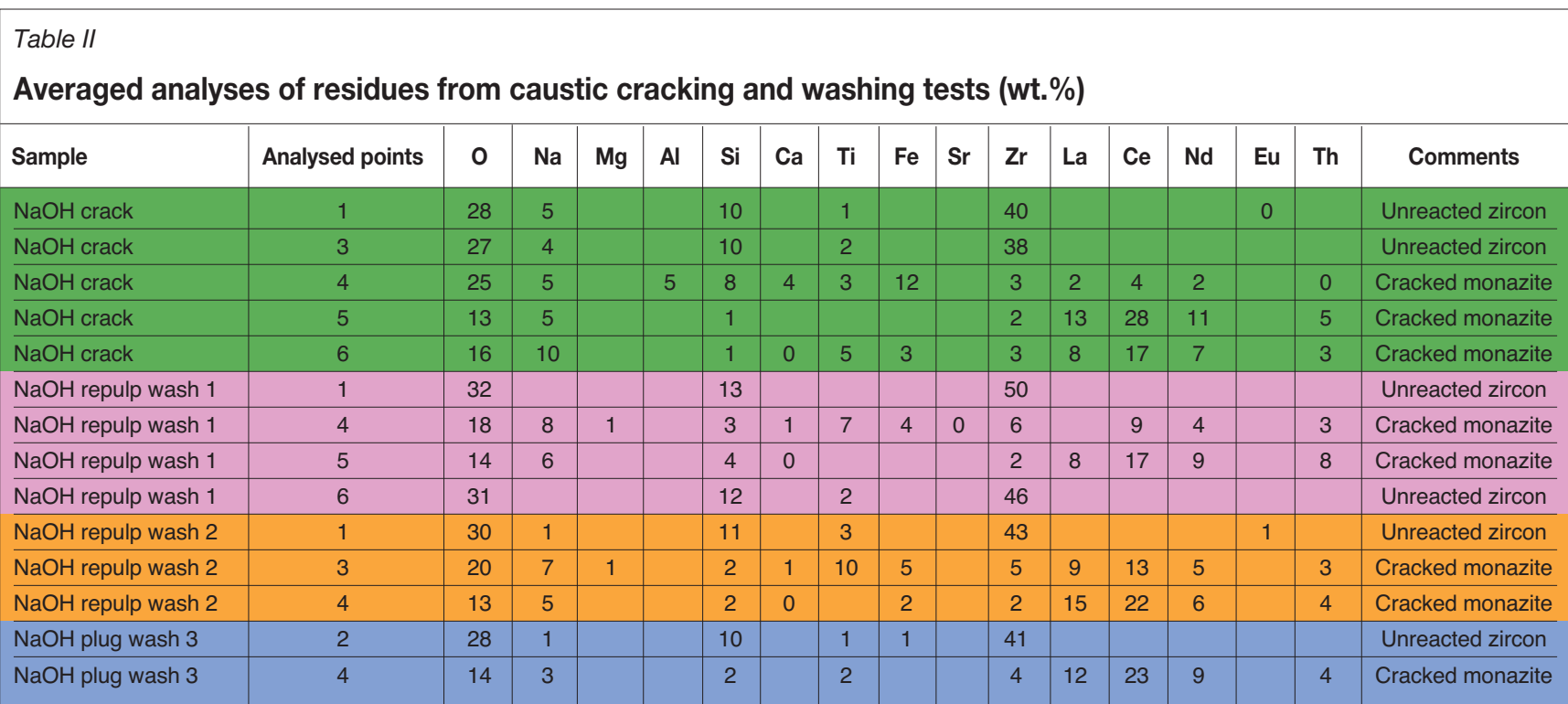

${ }^{*}$ Note that as powdered material was examined, EDS data is not quantitative, but will give an indication of the types of phases present

The third wash, which was the plug wash, was aimed at further removal of $\mathrm{NaOH}$ solution entrained in the residue. The removal of $\mathrm{NaOH}$ across three washes yielded similar results in terms of $\mathrm{Na}$ content (Table II).

\section{Water leach residues}

The mineralogical results showed that the REE-containing phases are compounds containing a mixture of $\mathrm{Ce}, \mathrm{La}$, and Th with $\mathrm{Al}, \mathrm{Mg}, \mathrm{Si}, \mathrm{Ca}$, and Fe. (Figure 6 and Table III). The zircon grains remained unreacted from this procedure; this is expected, since zircon failed to react with $\mathrm{NaOH}$ at a temperature of $140^{\circ} \mathrm{C}$. The decomposition of zircon occurs at temperatures higher than $500^{\circ} \mathrm{C}$ (Farias da Silva, Dutra, and Afonso, (2012).
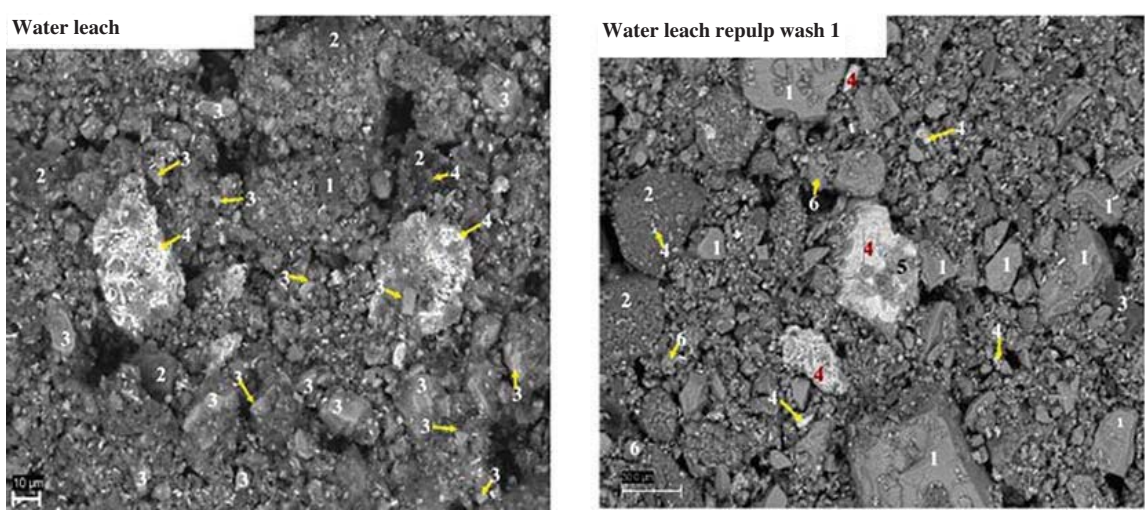

Figure 6-Backscattered electron (BSE) images of residues from water leaching and washing tests; analyses of the numbered points are given in Table III. The BSE images also show the cracked monazite grains and unreacted zircon. (The numbered points 1 and 3 of water leach product and points 2,3 and 4 of the water leach repulp wash 1 refer to oxide and silicate phases)

Table III

Averaged analyses of water leaching and washing tests residues (wt.\%)

\begin{tabular}{|l|c|c|c|c|c|c|c|c|c|c|c|c|c|c|c|c|c|}
\hline Sample & $\begin{array}{c}\text { Analysed } \\
\text { points }\end{array}$ & $\mathbf{0}$ & $\mathbf{N a}$ & $\mathbf{M g}$ & $\mathbf{A l}$ & $\mathbf{S i}$ & $\mathbf{C a}$ & $\mathbf{T i}$ & $\mathbf{F e}$ & $\mathbf{S r}$ & $\mathbf{Z r}$ & $\mathbf{L a}$ & $\mathbf{C e}$ & $\mathbf{N d}$ & $\mathbf{E u}$ & $\mathbf{T h}$ & $\mathbf{C o m m e n t s}$ \\
\hline Water leach & 2 & 27 & & & & 11 & & 1 & & 42 & & \\
\hline Water leach & 4 & 13 & 2 & & 0 & 1 & & 2 & & & 14 & 29 & 9 & 6 & Cracked monazite \\
\hline Water leach repulp wash 1 & 1 & 23 & & & & 9 & & & & & 36 & & & & & \\
\hline Water leach repulp wash 1 & 5 & 25 & & & & 10 & & 1 & & 38 & & & & 0 & \\
\hline
\end{tabular}

*Note that as powdered material was examined, EDS data is not quantitative, but will give an indication of the types of phases present 


\section{The application of process mineralogy on a tailings sample containing REE}

The SEM analysis confirmed the presence of $\mathrm{Eu}$ in some of the zircon grains and also showed the consistent $\mathrm{Zr}$ :Si ratio of unreacted zircon grains. There were no notable differences between the residues from the water leach and repulp wash. The REE-containing phases are likely to be converted into hydroxides during the water leach process (Table III), which was the aim of this step.

\section{Selective $(\mathrm{HCl})$ leaching residues}

The water leach repulp washed residues were subjected to $\mathrm{HCl}$ leaching for 4 hours at a $\mathrm{pH}$ of 3 under ambient temperature at varying redox potentials of $\mathrm{pH}$ levels 4.1 to 3.054. The $\mathrm{HCl}$ leach and subsequent washes successfully removed the remaining $\mathrm{Na}$ from the water-washed residue (Table III). A decrease is observed in $\mathrm{La}, \mathrm{Nd}$, and Ce contents relative to the first two stages (Tables II and III), indicating the successful solubilization of these elements by $\mathrm{HCl}$ leaching. Th concentrations were found to increase markedly compared with the first two stages (Tables II, III, and IV). Some of the REE-containing phases showed associations with $\mathrm{Al}, \mathrm{Si}, \mathrm{Ca}, \mathrm{Mg}$, and $\mathrm{Fe}$ compounds (Figure 7 and Table IV).

Table IV

Averaged analyses of $\mathrm{HCl}$ leaching and washing test residues (wt. \%)

\begin{tabular}{|c|c|c|c|c|c|c|c|c|c|c|c|c|c|c|c|c|}
\hline Sample & Analysed points & 0 & $\mathrm{Na}$ & $\mathrm{Mg}$ & Al & $\mathrm{Si}$ & C1 & $\mathrm{Ca}$ & $\mathrm{Ti}$ & $\mathrm{Fe}$ & $\mathrm{Zr}$ & La & $\mathrm{Ce}$ & Nd & Th & Comments \\
\hline $\mathrm{HCl}$ leach unwashed & 1 & 23 & & & & 9 & & & & & 36 & & & & & Unreacted zircon \\
\hline $\mathrm{HCl}$ leach unwashed & 7 & 18 & & & & 3 & & 0 & & 2 & & 8 & 14 & 6 & 3 & Cracked monazite \\
\hline $\mathrm{HCl}$ leach wash 1 & 2 & 25 & & & & 9 & & & 2 & 1 & 36 & & & & & Unreacted zircon \\
\hline $\mathrm{HCl}$ leach wash 1 & 3 & 24 & & & & 8 & & & 4 & 2 & 33 & & & & & Unreacted zircon \\
\hline $\mathrm{HCl}$ leach wash 1 & 6 & 20 & & & & 1 & & 0 & & 1 & & 9 & 17 & 6 & 3 & Cracked monazite \\
\hline $\mathrm{HCl}$ leach wash 1 & 7 & 18 & & & & 3 & & 0 & & 2 & & 8 & 14 & 6 & 3 & Cracked monazite \\
\hline $\mathrm{HCl}$ leach wash 2 & 3 & 25 & & & & 10 & & & & & 39 & & & & & Unreacted zircon \\
\hline $\mathrm{HCl}$ leach wash 2 & 5 & 13 & & & & 2 & & & 5 & 3 & 4 & & 17 & & 11 & Cracked monazite \\
\hline $\mathrm{HCl}$ leach wash 2 & 6 & 12 & & & & 2 & & & 5 & 2 & 5 & & 13 & & 11 & Cracked monazite \\
\hline $\mathrm{HCl}$ leach wash 2 & 7 & 16 & & & & 3 & & & 6 & 3 & 8 & & 4 & & 31 & Cracked monazite \\
\hline $\mathrm{HCl}$ leach wash 3 & 1 & 25 & & & & 10 & & & & & 39 & & & & & Unreacted zircon \\
\hline $\mathrm{HCl}$ leach wash 3 & 2 & 18 & & & 0 & 4 & & 0 & 3 & 2 & 9 & 4 & 8 & 3 & 24 & Cracked monazite \\
\hline $\mathrm{HCl}$ leach wash 3 & 3 & 18 & & & & 3 & & & 9 & 5 & 7 & & 7 & & 18 & Cracked monazite \\
\hline $\mathrm{HCl}$ leach wash 3 & 6 & 29 & & & & 11 & & & 4 & 2 & 39 & & & & & Unreacted zircon \\
\hline
\end{tabular}

*Note that as powdered material was examined, EDS data is not quantitative, but will give an indication of the types of phases present
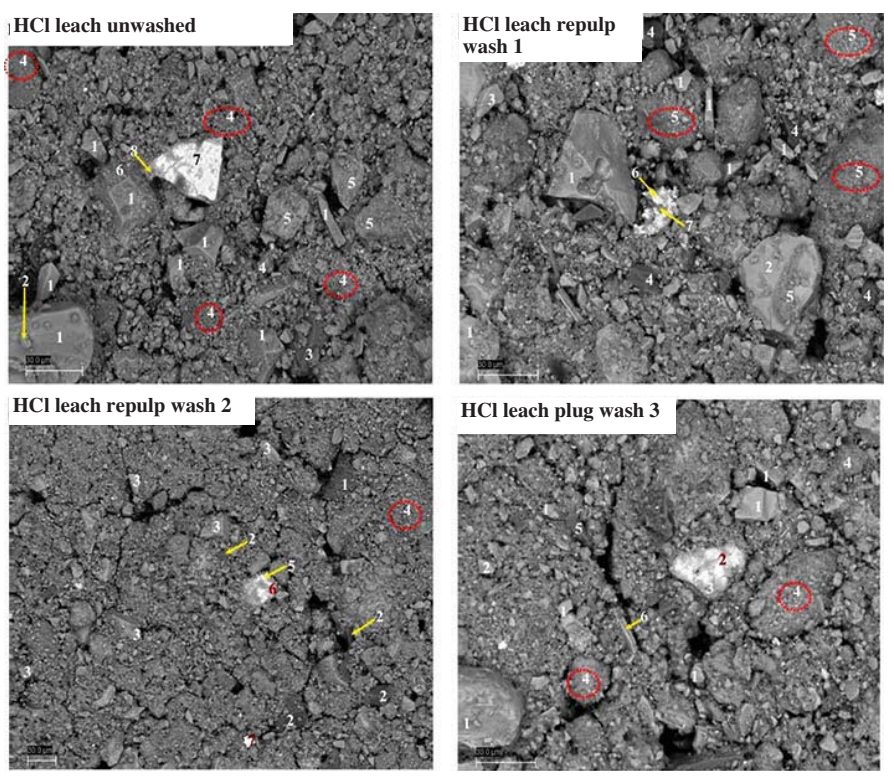

Figure 7-BSE images of residues from $\mathrm{HCl}$ leaching and washing tests; analyses of the numbered points are given in Table IV. The BSE images also show the cracked monazite grains and unreacted zircon. Circles indicate fine-grained phases. (Points 2 to 6 and 8 of $\mathrm{HCl}$ leach unwashed; points 1, 4, and 5 of $\mathrm{HCl}$ repulp wash 1; points 1, 2, and 4 of $\mathrm{HCl}$ leach wash 2, and points 4 and 5 of $\mathrm{HCl}$ leach wash 3 refer to oxide and silicate phases) 


\section{The application of process mineralogy on a tailings sample containing REE}

\section{Conclusion}

This investigation has demonstrated that mineralogical characterization plays a vital role in processing method selection for REE. Detailed mineralogical characterization of the as-received tailings sample showed that the key REEbearing minerals, monazite and zircon, were naturally concentrated in the two finer size fractions $(-150$ and $-106 \mu \mathrm{m})$, hence these composited fractions were subjected to direct leaching. This shows the value of introducing mineralogical characterization of the ore before embarking on any REE extraction processes.

The phosphate ion of monazite was successfully removed by $\mathrm{NaOH}$ cracking. $\mathrm{NaOH}$ is highly reactive towards monazite, but the $\mathrm{NaOH}$ did not react with zircon. The $\mathrm{NaOH}$ leaching temperature is therefore sufficient for phosphate ion cracking but not sufficient to crack the silica within the zircon structure $\left(\mathrm{ZrSiO}_{4}\right)$, as shown by the consistent ratio of $\mathrm{Zr}$ to $\mathrm{Si}$ in the EDS analyses. During the $\mathrm{NaOH}$ cracking process, it was anticipated that the $\mathrm{NaOH}$ would decrease with each wash; however, both the plug and the two repulp wash residues returned similar phase chemistries, based on the mineralogical observations of the Na content.

Water leaching of the residue from cracking enhanced the removal of $\mathrm{NaOH}$ solution, and likely converted the cracked monazite into REE hydroxides. The REE-containing phases were also associated with $\mathrm{Al}, \mathrm{Si}, \mathrm{Ca}$, and $\mathrm{Fe}$. Examination of the residues from selective $\mathrm{HCl}$ leaching and washing showed that remnant $\mathrm{Na}$ from $\mathrm{NaOH}$ was entirely removed during the leaching.

The decrease in REE content of phases from the second to the third stage (i.e. water leach to $\mathrm{HCl}$ leach) indicates that REE dissolution by $\mathrm{HCl}$ took place. This will be quantified by bulk chemical analysis of the products. Subsequently, the Th content tends to increase drastically, indicating that Th is not solubilized through $\mathrm{HCl}$ leaching.

Finally, the mineralogical analysis shows that monazite cracking and subsequent leaching of REE appear to have been successful. Further test work will be required, as guided by the recovery data, to obtain the optimum REE extraction from the composite sample.

Thus far, this study shows that by conducting mineralogical investigations beforehand, it is possible to minimize other stages of mineral processing such as ore upgrading or production of a concentrate prior to hydrometallurgical treatment. Based on the mineralogical investigation, it was observed that monazite and zircon were naturally concentrated in the finer fractions $(-150+106$ and $-106 \mu \mathrm{m}$ ), which constituted approximately 50 mass $\%$ of the sample. These two size fractions were therefore composited prior to direct leaching. Mineralogical studies on the leach products also provide insights into REE extraction. Together, these investigations are indispensable when developing suitable process and extraction flow sheets.

\section{References}

ChEGwidDEn, J. and KingSNORTH, D.J. 2010. Rare earths: facing the uncertainties of supply. Proceedings of the 6th International Rare Earths Conference, Hong Kong, November 2010. http://www.slideshare.net/Tehama/rareearths-facing-the-uncertaintys-of-supply
DeYSEL, K. 2007. Leucoxene study: A mineral liberation analysis (MLA) investigation. Proceedings of the 6th International Heavy Minerals Conference 'Back to Basics', Richards Bay Minerals, Natal, South Africa. Southern African Institute of Mining and Metallurgy, Johannesburg. pp. 167-172.

Farias Da Silva, J.R., Dutra, A.J.B., and Afonso, J.C. 2012. Alkali fusion followed by a two-step leaching of a Brazilian zircon concentrate. Hydrometallurgy, vol. 117-118. pp. 93-100.

FAtherly, N., O'Neill, M., and GlemZA, A. 2008. Formerly used sites remedial action program (FUSRAP) W.R. Grace feasibility study (FS) alternative development process challenges and successes. Proceedings of WM'08: Waste Management Symposium, Phoenix, AZ, 24-28 February 2008. http:// http://www.wmsym.org/archives/2008/pdfs/8255.pdf

GoRDon, J. 2011. Analysis: underwater rare earths likely a pipe dream. http://www.reuters.com/article/2011/07/06/us-rareearths-underwateridUSTRE7655M320110706

GuPTA, C.K. and Krishnamurthy, N. 2005. Extractive Metallurgy of Rare Earths. CRC Press, Boca Raton, FL. 502 pp.

HAXeL, G.B., HEDRICK, J.B., and ORRIS, G.J. 2002. Rare earth elements-critical resources for high technology. Fact sheet 087-02. US Geological Survey, Reston, VA.

Liu, Y. 2011. A rare earths crisis. Queen's Business Review. http://www.qbreview.org/a-rare-earths-crisis/ [accessed July 2014].

MASSARI, S. and RUBERTI, M. 2013. Rare earth elements as critical raw materials: Focus on international markets and future strategies. Resources Policy, vol. 23, pp. 36-48.

Мокоеnа, S. 2016. Personal communication. Hydrometallurgy Division, Mintek, Randburg, South Africa.

MonTGomery, M. 2011. Rare earths recycling enter the new reality. IB Times, 23 February. http://www.ibtimes.com/articles/115379/20110223/rareearth-recycling-enter-the-new-reality.htm

MoRRISON, W.M. and TANG, R. 2012. China's rare earth industry and export regime. Economic and trade implications for the United States. Congressional Research Service Report. pp. 1-36

PAWLIK, C. 2013. Recovery of rare earth elements from complex and low grade deposits. Proceedings of the ALTA Uranium-REE Conference, Perth, 25 May-1 June. Alta Metallurgical Services.

Roskill. 2015. Rare Earths: Market Outlook to 2020. 15th edn.

SAPPIN, A.A. and Beaudoin, G. 2015. Rare earth elements in Québec, Canada: Main deposit types and their economic potential. Proceedings of the Symposium on Strategic and Critical Materials, Victoria, British Columbia, 13-14 November 2015. Simandl, G.J. and Neetz, M. (eds.). British Columbia Ministry of Energy and Mines. British Columbia Geological Survey Paper 2015-3. pp. 265-273.

TABuKi, H. 2010. Japan recycles minerals from used electronics. New York Times, 4 October. http://www.nytimes.com/2010/10/05/business/global/ 05recycle.html

WüBBEKE, J. 2013. Rare earth elements in China: Policies and narratives of reinventing an industry. Resources Policy, vol. 38. pp. 384-394. 